\title{
Characterization of a reactive yellow-2 decolorizing zinc tolerant bacterial strain Pseudomonas sp. LT10 isolated from textile industry wastewater
}

\author{
Abdul Mateen Baig1, Tauseef Sarwar², Lubna Taj1, Yasir Bilal1', Etisam Mazhar¹, Hafiz Rizwan Elahi1, \\ Muhammad Mazhar Iqbal ${ }^{3}$, Asima Rasheed ${ }^{4}$, Zahid Maqbool ${ }^{1}$, Sabir Hussain ${ }^{*}$ \\ ${ }^{1}$ Department of Environmental Sciences \& Engineering, Government College University Faisalabad, Pakistan. \\ ${ }^{2}$ Department of Microbiology, Government College University Faisalabad, Pakistan. \\ ${ }^{3}$ Soil and Water Testing Laboratory for Research, Chiniot, Department of Agriculture, Government of Punjab, Pakistaan. \\ ${ }^{4}$ Department of Bioinformatics \& Biotechnology, Government College University Faisalabad, Pakistan.
}

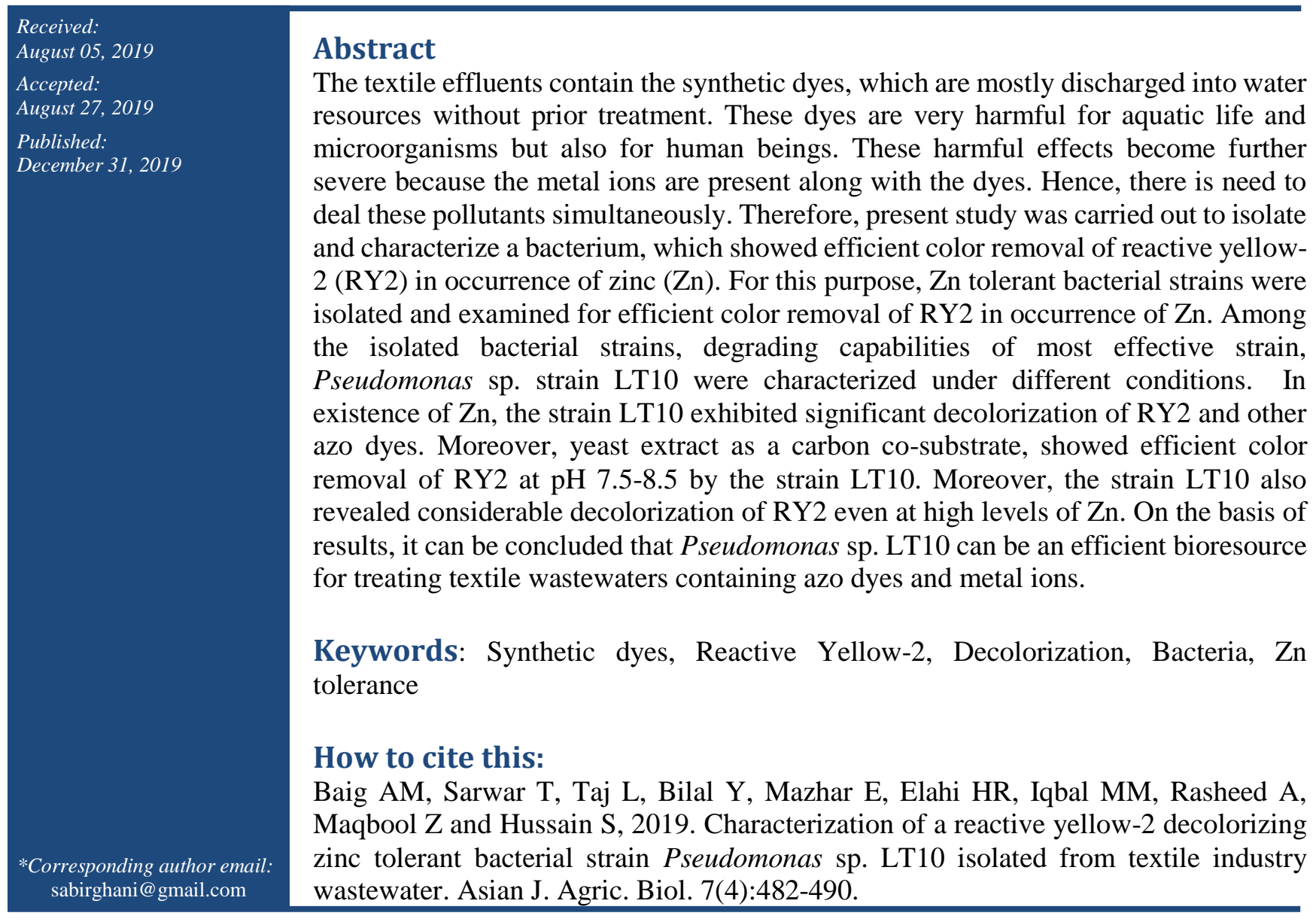

This is an Open Access article distributed under the terms of the Creative Commons Attribution 3.0 License. (https://creativecommons.org/licenses/by/3.0), which permits unrestricted use, distribution, and reproduction in any medium, provided the original work is properly cited.

\section{Introduction}

Textile sector plays a significant role in the economy of several countries and contemporarily becoming central cause of environmental pollution worldwide due to release of enormous amounts of wastewater
(Mondal et al., 2017). The consumption of water in textile industries is very high and almost $90 \%$ of the total consumed water is released as wastewater (Verma et al., 2012; Imran et al., 2015). Textile wastewater contains many types of dyes, which act as major pollutants in wastewater (Imran et al., 2015). 
These dyes are recalcitrant in nature and impart intense color to textile wastewater (Mondal et al., 2017). The unsuitable disposal of textile wastewater causes reduction in penetration of sunlight in aqueous ecosystem, which results in reduced photosynthetic activity and causes acute toxicity in aquatic flora and fauna (Imran et al., 2015; Mondal et al., 2017).

Azo dyes are the synthetic dyes, which contain nitrogen to nitrogen double bond and the most frequently used dyes in textile and pharmaceutical industry (Imran et al., 2015). According to some estimates, about $50 \%$ of the applied dyes is released as wastewater during the textile dyeing processes (Carliell et al., 1995; Kusic et al., 2011). Their release in environment cause displeasing odor and color in the water bodies (Chacko and Subramaniam, 2011). These dyes also reported to alter COD, BOD and TOC for aquatic organisms (Saratale et al., 2009: Chacko and Subramaniam, 2011). It has been stated that few azo dyes and their metabolites are toxic and mutagenic in nature, causing serious threats to living organisms including human beings (Phugare et al., 2011). These dyes not only affect germination, growth and production of plants but also disturb microbial activities in soil (Ghodake et al., 2009; Imran et al., 2015). Plants growth is also suppressed by high concentration of these dyes (Dawkar et al., 2008; Khadhraoui et al., 2009; Phugare et al., 2011). In case of exposure to human beings, several problems including diarrhea, dermatitis, irritation of respiratory track and mucous membrane ulceration have been reported to be caused (Mittal et al., 2005). Even though high molecular weight and aromatic ring structure enable the azo dyes to resist degradation process, there is a need to remediate the effluents containing these dyes.

Several physic-chemical technologies including adsorption, coagulation, chemical transformation and irradiation have been described to be exploited for remediation of textile wastewaters (Chacko and Subramaniam, 2011). However, physicochemical technologies are not preferred because of their higher cost and not being environmental friendly. Biological technologies involve microbial decolorization of textile wastewaters and preferred due to their less cost and environment friendly nature (Tripathi and Srivastave, 2011; Mahmood et al., 2012; Imran et al., 2015; Maqbool et al., 2018). As few fungal species have also been found in dye removal process (Hussain et al., 2017) but the bacterial strains are given priority because of their shorter life span and rapid degradation process (Verma and Madamwar, 2003; Elisangela et al., 2009; Imran et al., 2015). Previous scientist have isolated a number of bacteria belonged to different genera and studied their potential for decolorization of various azo dyes e.g., Enterobacter (Roy et al., 2018), Acinetobacter (Meerbergen et al., 2018), Arthrospira maxima (Afreen et al., 2016), Staphylococcus aureus (Ayed et al., 2017), Shewanella (Imran et al., 2014) and Serratia (Najme et al., 2015). Moreover the existence of metal ions including zinc, cadmium, chromium, copper, nickel etc. significantly affect the dye decolorizing activity of bacterial strains (Hafeez et al., 2018; Maqbool et al., 2018). As these metal ions are also a component of the textile wastewaters, hence, there is need to isolate and characterize bacterial strains able to decolorize azo-dyes while tolerating the existence of such metal ions.

Zinc $(\mathrm{Zn})$ is one of the heavy metals, which has been stated as a contaminant in the wastewaters produced from different industries including the textile dyeing units. However, presence of $\mathrm{Zn}$ in the textile wastewaters influence growth and activity of azo dyes degrading bacterial strains (Hussain et al., 2013; Imran et al., 2015). Therefore, it is a prerequisite to isolate bacterial strains proficient in not only decolorizing azo dyes but also show resistance towards existence of $\mathrm{Zn}$ in the media. Therefore, this study was carried out to isolate and characterize a $\mathrm{Zn}$ tolerant bacterium for decolorization of azo dyes in occurrence of $\mathrm{Zn}$.

\section{Material and Methods}

\section{Dyes, chemicals and culture media}

The azo-dyes used in present experimental study were obtained either from Sigma-Aldrich (Germany). Analytical grade chemicals and reagents were used and purchased from Sigma- Aldrich. Zinc tolerant bacteria were isolated by using mineral salt media (MSM), which contained $\mathrm{NaCl}\left(1 \mathrm{~g} \mathrm{~L}^{-1}\right), \mathrm{MgSO}_{4} .7 \mathrm{H}_{2} \mathrm{O}$ $\left(0.5 \mathrm{~g} \mathrm{~L}^{-1}\right), \mathrm{CaCl}_{2} .2 \mathrm{H}_{2} \mathrm{O}\left(0.1 \mathrm{~g} \mathrm{~L}^{-1}\right), \mathrm{K}_{2} \mathrm{HPO}_{4}\left(1 \mathrm{~g} \mathrm{~L}^{-1}\right)$, $\mathrm{KH}_{2} \mathrm{PO}_{4}\left(1 \mathrm{~g} \mathrm{~L}^{-1}\right)$ and yeast extract $\left(3 \mathrm{~g} \mathrm{~L}^{-1}\right)$. In general, the $\mathrm{pH}$ of the medium was adjusted at 7.2 and $200 \mathrm{mg}$ $\mathrm{L}^{-1}$ of $\mathrm{Zn}$ using $\mathrm{Zn}\left(\mathrm{NO}_{3}\right)_{2}$ and $200 \mathrm{mg} / \mathrm{L}$ of $\mathrm{RY} 2$ were also added in MSM in order to isolate bacterial strains that have the potential of dyes decolorization in presence of zinc. Standard $\mathrm{NaOH}$ or $\mathrm{HCl}$ was used to adjust the $\mathrm{pH}$ of MSM whenever it was required. Nutrient agar (NA) medium with composition $\left(\mathrm{g} \mathrm{L}^{-1}\right)$ $\mathrm{NaCl}$ (5.0), yeast extract (2), peptone (5) and agar (15) was used for determining minimum inhibitory 
concentration (MIC) of $\mathrm{Zn}$ and other metal ions for the bacterial strains and to estimate the bacterial population density.

\section{Isolation of Zn tolerant RY2 decolorizing strain LT10}

To isolate $\mathrm{Zn}$ tolerant RY2 decolorizing bacterial strain, the industrial effluents were sampled from different textile industries in Faisalabad. The $\mathrm{pH}$ of all the collected samples was alkaline and electrical conductivity (EC) of all the samples was greater than $5 \mathrm{dS} \mathrm{m} \mathrm{m}^{-1}$. For the isolation of $\mathrm{Zn}$ resistant $\mathrm{RY} 2$ decolorizing bacteria, enrichment culture technique was adopted using MSM broth containing $200 \mathrm{mg} \mathrm{L}^{-1}$ of $\mathrm{Zn}$ and $200 \mathrm{mg} \mathrm{L}^{-1}$ of RY2 dye. For enrichment, each waste water sample was inoculated into MSM broth $(1: 10)$ in individual flask and incubated in dark at $30^{\circ} \mathrm{C}$ in static incubator together with un-inoculated control. After an incubation period of $72 \mathrm{~h}$, the aliquots were taken from each flask and subjected to centrifugation (6000 rpm for 5 minutes $)$ and decolorization of RY2 was analyzed by making a comparison of absorbance ( $\lambda_{\max }=404 \mathrm{~nm}$ on a UVVisible Spectrophotometer) of aliquots in inoculated media and controls through the following formula:

Decolorization $(\%)=\frac{(\text { Uninoculated control }- \text { Inoculated sample })}{\text { Uninoculated control }} \times 100$

When $<50 \%$ of added RY2 was decolorized, samples were taken from 1st enrichment and mixed with freshly prepared MSM broth (1:10) amended with $\mathrm{RY} 2$ and $\mathrm{Zn}$. The second batch of enrichment cultures was treated in the same way as the first batch and again decolorization was estimated as described above. After five cycles, sample from each culture was spread on $\mathrm{MS}+\mathrm{Zn}+\mathrm{RY} 2$ agar plates through dilution plate technique and incubated in dark at $30^{\circ} \mathrm{C}$. After $72 \mathrm{~h}$, 35 dissimilar bacterial colonies were selected on the base of their rapid growth and different morphology and purified through repeated streaking method using MSM agar plates. The single purified colonies were examined for color removal of RY2 in occurrence of $\mathrm{Zn}$ in MSM broth medium. The purified 35 bacterial isolates were transferred to MS broth media containing $\mathrm{Zn}(200 \mathrm{mg} / \mathrm{L})$. After $24 \mathrm{~h}$, growth of each bacterial isolates was checked by measuring their optical density (OD) at $600 \mathrm{~nm}$. $2.0 \mathrm{~mL}$ of each bacterial culture was inoculated distinctively in triplicates containing $18 \mathrm{~mL}$ of MS broth media with an addition of $\mathrm{Zn}(200 \mathrm{mg} / \mathrm{L})$ and RY2 $(200 \mathrm{mg} / \mathrm{L})$. All the samples together with un-inoculated control were incubated at $30^{\circ} \mathrm{C}$ in static incubator. After $48 \mathrm{~h}$ incubation, samples from all cultures were taken and centrifuged at $6000 \mathrm{rpm}$ for $5 \mathrm{~min}$, supernatants were analyzed for RY2 color removal as already described above. All the 35 isolates were also assessed for their $\mathrm{Zn}$ tolerance by estimating the MIC of $\mathrm{Zn}$ against them. For this purpose, all the isolates were grown on NA plates containing different concentrations of $\mathrm{Zn}$ (200 to $3000 \mathrm{mg} \mathrm{L}^{-1}$ ). The minimum concentration of $\mathrm{Zn}$ at which some bacterial isolate could not grow was considered MIC of $\mathrm{Zn}$ for that bacterial isolate. From this screening, the isolate LT10 showed highest decolorization of RY2 and exhibited high MIC value of $\mathrm{Zn}$, and therefore selected for further characterization.

\section{Amplification and sequencing of 16S rDNA of strain LT10}

The amplification and sequencing of 16S rDNA gene was done for identification of the isolate LT10. The $16 \mathrm{~S}$ rDNA gene amplification of the isolate LT10 was done by the process as reported by Maqbool et al. (2016). The purification and sequencing of the amplified 16S rDNA gene was done by Macrogen (Seol, South Korea). By using the online BlastN program of National Center for Biotechnology Information (NCBI), the $16 \mathrm{~S}$ rDNA sequence of LT10 was compared with other known sequences. Phylogenetic analysis of this sequence based on multiple alignments followed by construction of phylogenetic tree through neighbor joining method was carried out as previously reported by Maqbool et al. (2016).

\section{Optimization of decolorizing ability of LT10 at different incubation conditions}

Color removal of RY2 by LT10 at different pH

The potential of strain LT10 for RY2 color removal $(200 \mathrm{mg} / \mathrm{L})$ in MSM containing $\mathrm{Zn}\left(200 \mathrm{mg} \mathrm{L}^{-1}\right)$ was evaluated at different $\mathrm{pH}$ including 5.5, 6.5, 7.5, 8.5 and 9.5. For this purpose, $\mathrm{pH}$ of the MSM broth media was maintained using standard $\mathrm{HCl}$ and $\mathrm{NaOH}$ solutions. The MSM liquid media adjusted with RY2 (200 mg/L) and $\mathrm{Zn}(200 \mathrm{mg} / \mathrm{L})$ were inoculated with the bacterial culture of LT10 to obtain $\mathrm{OD}_{600}$ of 0.1 . The triplicates of inoculated media together with controls were preserved in static incubator. The aliquots were taken after consistent incubation period (24, 48, 72, 96 and $120 \mathrm{~h}$ ), subjected to centrifugation (6000 rpm for $5 \mathrm{~min}$ ) and used for measuring RY2 decolorization through UV-visible spectrophotometer as described above. 


\section{Color removal of RY2 by LT10 in the presence of varying carbon co-substrates}

The ability of the strain LT10 for color removal of RY2 (200 mg/L) in MS broth media altered with Zn $(200 \mathrm{mg} / \mathrm{L})$ was evaluated in the presence of varying carbon (C) co-substrates including glucose, lactose, sucrose, maltose, yeast extract and D-Mannitol. Therefore, the media altered with RY2 (200 mg/L) and $\mathrm{Zn}\left(200 \mathrm{mg} \mathrm{L}^{-1}\right)$ were separately added with $3 \mathrm{~g} \mathrm{~L}^{-1}$ of the individual carbon co-substrates and then bacterial cells of LT10 were added in MSM to obtain OD $_{600}$ of 0.1 . The triplicates of inoculated samples together with their respective controls were placed in static incubator at $30^{\circ} \mathrm{C}$. The aliquots were drawn after 16 and $40 \mathrm{~h}$ of incubation, subjected to centrifugation (6000 rpm for 5 minutes) and used for measuring RY2 decolorization through UV-visible spectrophotometer as explained above.

\section{Decolorization of RY2 by LT10 at different concentrations of $\mathbf{Z n}$}

The capability of the LT10 bacterial isolate for decolorization of RY2 $(200 \mathrm{mg} / \mathrm{L})$ was also evaluated at varying concentrations of $\mathrm{Zn}$ including 200, 500, $800,1000,1500$ and $2000 \mathrm{mg} / \mathrm{L}$ of $\mathrm{Zn}$ in the MS broth media. The separate MS broth media containing RY2 $(200 \mathrm{mg} / \mathrm{L})$ and above different concentrations of $\mathrm{Zn}$ were subjected to inoculation with the bacterial cells of LT10 to achieve $\mathrm{OD}_{600}$ of 0.1. The triplicates of inoculated media together with their respective controls were placed in static incubator at $30^{\circ} \mathrm{C}$ in dark. The aliquots were drawn after planned intervals, subjected to centrifugation (6000 rpm for $5 \mathrm{~min}$ ) and used for measuring RY2 decolorization as already described above.

\section{Color removal of structurally different azo dyes by LT10 in the presence of Zn}

The strain LT10 was also studied for its potential to remove color of different azo dyes such as RY2, RR120, RO16, RB5, CRD, OD, BD and VD in MSM broth media altered with $\mathrm{Zn}(200 \mathrm{mg} / \mathrm{L})$. For this purpose, all these dyes were individually added (@ $200 \mathrm{mg} / \mathrm{L}$ ) in the separate MS liquid media containing $\mathrm{Zn}(200 \mathrm{mg} / \mathrm{L})$ and then inoculation with the cells of LT10 was carried out to achieve $\mathrm{OD}_{600}$ of 0.1 . The triplicates of inoculated media along with their respective un-inoculated controls were placed in static incubator. The supernatants from all samples were drawn after 24, 48, 72, 96, 120 and $144 \mathrm{~h}$, subjected to centrifugation (6000 rpm for 5 minutes) and used for determining decolorization of each azo-dye using spectrophotometer at particular $\lambda_{\max }$ values $(\mathrm{RY} 2=$ $404 \mathrm{~nm}, \mathrm{RB} 5=597 \mathrm{~nm}, \mathrm{RR} 120=535 \mathrm{~nm}, \mathrm{RO} 16=$ $494 \mathrm{~nm}, \mathrm{CRD}=540 \mathrm{~nm}, \mathrm{OD}=496 \mathrm{~nm}, \mathrm{BD}=580 \mathrm{~nm}$, $\mathrm{VD}=510 \mathrm{~nm}$ ) for each dyes. The decolorization of each dye was estimated using the equation already given above.

\section{Results}

\section{Isolation, screening and identification of LT10}

This study demonstrated the isolation of several bacteria from textile wastewater samples collected from various textile industries located in Faisalabad. Among the isolated bacteria, 35 different bacterial isolates were examined for color removal RY2 as well as their ability to tolerate $\mathrm{Zn}$ in MSM medium. All the 35 isolates were found to decolorize (>10\%) RY2 in MSM altered with $200 \mathrm{mg} / \mathrm{L}$ of $\mathrm{Zn}$ but with varying extents ranging from $10.9 \pm 1.2 \%$ to $90.8 \pm 2.5 \%$ (Table 1 ). Such variation might be due to variation in decolorizing capabilities of the isolates and their involved enzymatic systems. Such variation has also been described in different studies dealing with bacterial decolorization of several azo dyes (Maqbool et al., 2016; Hafeez et al., 2018; Maqbool et al., 2018). However, this study is different from others because in this study the decolorization was conducted in the existence of $200 \mathrm{mg} / \mathrm{L}$ of $\mathrm{Zn}$. It was also observed that 13 out of these 35 isolates including LT1, LT2, LT3, LT6, LT7, LT8, LT9, LT10, LT16, LT25, LT28, LT33 and LT34 were found to decolorize $>50 \%$ of the initially added RY2 within $48 \mathrm{~h}$. Among these isolates, the highest decolorization of RY2 was observed by the isolate LT10 as it had decolorized more than $90 \%$ of RY2 within $48 \mathrm{~h}$. Furthermore, it was observed that LT10 also had the ability to tolerate the presence of Zn because it was found to grow in MS medium even at $3000 \mathrm{mg} / \mathrm{L}$ of $\mathrm{Zn}$. Although some other isolates including LT14 and LT25 could also grow at this high concentration of $\mathrm{Zn}$ but they did not show a very good potential for RY2 decolonization.

From this study, the isolate LT10 was selected for further experiments because it exhibited highest RY2 decolorization at $200 \mathrm{mg} / \mathrm{L}$ of $\mathrm{Zn}$ as well as a good capability to resist the presence of greater concentration of $\mathrm{Zn}$. Based on BlastN analysis of its amplified 16S rDNA gene (NCBI GeneBank Accession No. KY492394), LT10 bacterial isolate was found to exhibit maximum resemblance with bacteria belonged to genus Pseudomonas. 
Table-1. Growth of the $\mathrm{Zn}$ resistant isolates at varying $\mathrm{Zn}$ concentrations and removal of $R Y 2$ by the isolates in the presence of $200 \mathrm{mg} \mathrm{L}^{-1}$ of $\mathrm{Zn}$

\begin{tabular}{|c|c|c|c|c|c|c|}
\hline \multirow{2}{*}{ Isolates } & \multicolumn{5}{|c|}{ Zn Concentration $\left(\mathrm{mg} \mathrm{L}^{-1}\right)$} & \multirow{2}{*}{$\begin{array}{c}\text { RY2 } \\
\text { Decolorization } \\
(\%) \\
\end{array}$} \\
\hline & 200 & 500 & 1000 & 2000 & 3000 & \\
\hline LT1 & + & + & -ve & -ve & -ve & $55.5 \pm 2.7$ \\
\hline LT2 & + & + & + & + & -ve & $71.3 \pm 1.8$ \\
\hline LT3 & + & + & $-\mathrm{ve}$ & $-\mathrm{ve}$ & -ve & $55.0 \pm 3.1$ \\
\hline LT4 & + & + & + & + & -ve & $45.5 \pm 2.4$ \\
\hline LT5 & + & + & + & -ve & -ve & $45.0 \pm 1.9$ \\
\hline LT6 & + & + & -ve & $-\mathrm{ve}$ & -ve & $76.5 \pm 1.8$ \\
\hline LT7 & + & + & -ve & -ve & -ve & $65.0 \pm 2.1$ \\
\hline LT8 & + & + & + & + & -ve & $66.5 \pm 2.5$ \\
\hline LT9 & + & + & + & -ve & -ve & $75.7 \pm 3.6$ \\
\hline LT10 & + & + & + & + & + & $90.8 \pm 2.5$ \\
\hline LT11 & + & + & $-v e$ & $-\mathrm{ve}$ & -ve & $33.9 \pm 2.2$ \\
\hline LT12 & + & + & + & -ve & -ve & $32.0 \pm 2.0$ \\
\hline LT13 & + & + & + & + & -ve & $23.0 \pm 1.2$ \\
\hline LT14 & + & + & + & + & + & $43.7 \pm 2.5$ \\
\hline LT15 & + & + & -ve & -ve & -ve & $40.0 \pm 1.9$ \\
\hline LT16 & + & + & + & -ve & -ve & $60.0 \pm 3.8$ \\
\hline LT17 & + & -ve & -ve & -ve & -ve & $34.6 \pm 2.4$ \\
\hline LT18 & + & + & + & + & -ve & $20.0 \pm 1.8$ \\
\hline LT19 & + & + & + & + & -ve & $15.7 \pm 1.0$ \\
\hline LT20 & + & -ve & -ve & -ve & -ve & $10.9 \pm 1.2$ \\
\hline LT21 & + & -ve & -ve & -ve & -ve & $15.0 \pm 1.1$ \\
\hline LT22 & + & + & + & + & -ve & $18.0 \pm 2.9$ \\
\hline LT23 & + & -ve & -ve & -ve & -ve & $20.8 \pm 2.0$ \\
\hline LT24 & + & + & -ve & -ve & -ve & $30.0 \pm 1.5$ \\
\hline LT25 & + & + & + & + & + & $55.0 \pm 2.4$ \\
\hline LT26 & + & + & + & -ve & -ve & $44.9 \pm 4.2$ \\
\hline LT27 & + & + & -ve & -ve & -ve & $34.0 \pm 2.7$ \\
\hline LT28 & + & + & + & + & -ve & $55.1 \pm 3.6$ \\
\hline LT29 & + & -ve & $-\mathrm{ve}$ & -ve & $-\mathrm{ve}$ & $20.4 \pm 2.7$ \\
\hline LT30 & + & + & + & + & -ve & $24.6 \pm 1.9$ \\
\hline LT31 & + & + & + & + & -ve & $15.5 \pm 2.6$ \\
\hline LT32 & + & + & + & + & $-\mathrm{ve}$ & $30.3 \pm 2.4$ \\
\hline LT33 & + & + & -ve & -ve & -ve & $50.0 \pm 1.1$ \\
\hline LT34 & + & + & + & -ve & -ve & $50.3 \pm 3.4$ \\
\hline LT35 & + & + & -ve & $-\mathrm{ve}$ & -ve & $18.0 \pm 2.8$ \\
\hline
\end{tabular}

Likewise, LT10 strain was also found to group with the bacteria belonging to genus Pseudomonas (Figure 1). Therefore, LT10 was named as Pseudomonas sp.
LT10 and its 16S rDNA sequence was deposited in NCBI Genebank with accession number KY492394. The previous published data indicated that few bacteria, which belong to genus Pseudomonas have already been reported for their potential to declorize several dyes (Jadhav et al., 2010; Maqbool et al., 2016; Hafeez et al., 2018). However, the bacteria isolated in this study i.e., Pseudomonas sp. LT10 is exceptional in the sense that it has considerable ability for RY2 decolorization even in the presence of $\mathrm{Zn}$. Very recently, Hafeez et al. (2018) reported the decolorizing ability of a bacterium, which belonged to genus Pseudomonas in the presence of lead $(\mathrm{Pb})$. Hence, the isolation of Pseudomonas sp. LT10 will be a potential addition to the existing dye decolorizing bacteria belonging to genus Pseudomonas with a special ability to decolorize even in $\mathrm{Zn}$ stress.

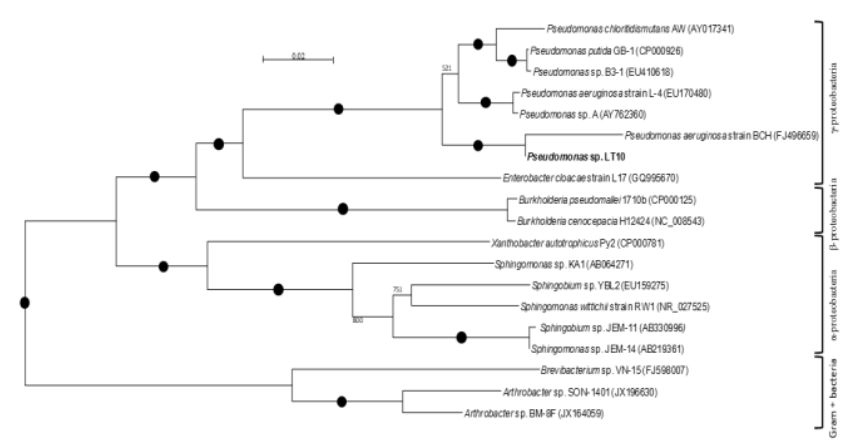

Fig-1: Phylogenetic tree based on 16S rDNA gene sequence of Pseudomonas sp. LT10.

\section{Impact of pH on color removal of RY2 by strain LT10}

The ability of Pseudomonas sp. LT10 for RY2 decolorization was evaluated at various levels of $\mathrm{pH}$ in MSM media altered with $200 \mathrm{mg} / \mathrm{L}$ of $\mathrm{Zn}$. Pseudomonas sp. LT10 exhibited considerable potential for color removal of RY2 at varying $\mathrm{pH}$ (5.5 to 9.5) (Figure 2).

However, this strain showed optimal decolorization at $\mathrm{pH}$ values of 7.5 and 8.5. After 24 hours, Pseudomonas sp. LT10 had decolorized 40.5\%, $41.7 \%, 21.1 \%, 20.8 \%$ and $8.9 \%$ of $\mathrm{RY} 2$ at $\mathrm{pH}$ values of 8.5, 7.5, 9.5, 6.5 and 5.5, respectively.

The maximum value of RY2 decolorization by the strain LT10 was recorded after 96, 72, 72, 48 and $48 \mathrm{~h}$ of incubation at $\mathrm{pH} 5.5,6.5,7.5,8.5$ and 9.5, respectively. Slightly alkaline $\mathrm{pH}$ value ranging from 7.0 to 8.5 has already been stated to be most promising for color removal of dyes by several previously isolated bacteria (Imran et al., 2014; Maqbool et al., 
2016; Hafeez et al., 2018; Maqbool et al., 2018). The differential decolorization at different $\mathrm{pH}$ may be attributed to effect of $\mathrm{pH}$ either on the decolorizing enzymes or on the growth of the bacterial strain as already reported for the strain Pseudomonas sp. RA20 while studying the decolorization of RB5 (Hussain et al., 2013).

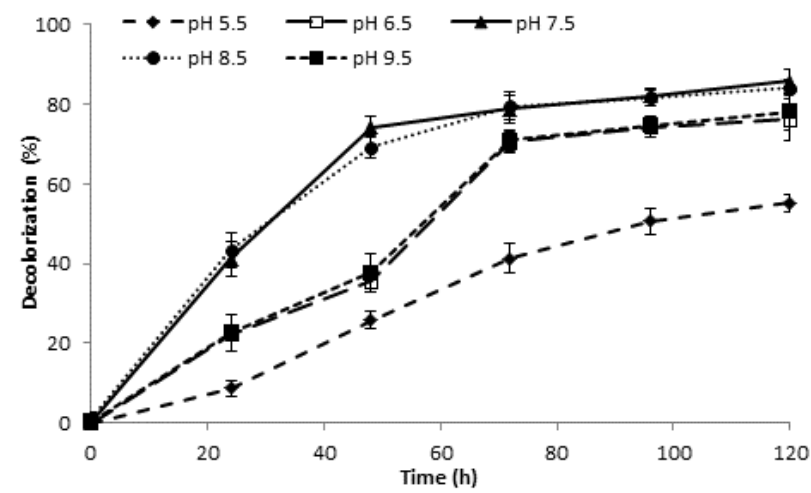

Fig-2: Removal of RY2 by Pseudomonas sp. LT10 at varying $\mathrm{pH}$ values in the presence of $200 \mathrm{mg} \mathrm{L}^{-1}$ of $\mathbf{Z n}$.

Impact of different carbon co-substrates on RY2 decolorization by Pseudomonas sp. LT10

Over $16 \mathrm{~h}$ incubation period, the strain LT10 decolorized 22.5, 22.9, 13.2, 4.6, 6.8 and 5.7\% of RY2 in the MSM broth amended with glucose, maltose, sucrose, lactose, yeast extract and D-Mannitol, respectively (Figure 3 ). However, over $40 \mathrm{~h}$ incubation period, it had decolorized 58.7, 44.1, 45.7, 16.8, 83.9 and $13.6 \%$ of RY2 in the MSM broth amended with glucose, maltose, sucrose, lactose, yeast extract and DMannitol, respectively. The increase in decolorizing abilities of bacterial strains against structurally dissimilar dyes in the existence of yeast extract has already been reported in several previous studies (Hussain et al., 2013; Imran et al., 2016; Maqbool et al., 2016; Hafeez et al., 2018). This increase in decolorization in the presence of yeast extract is attributed to its potential role not only in improving the growth of the bacterial strains but also in serving as a redox mediator for enzymes responsible for dye decolorization (Imran et al., 2016).

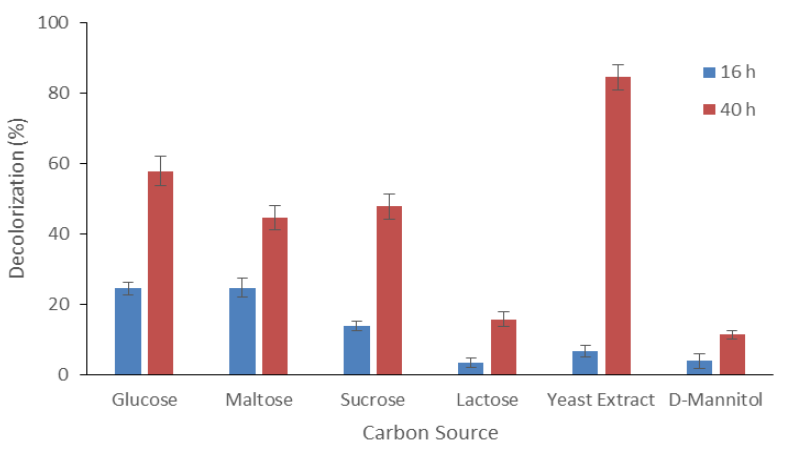

Fig-3: Removal of RY2 by Pseudomonas sp. LT10 in liquid culture containing different carbon cosubstrates in the presence of $200 \mathrm{mg} \mathrm{L}^{-1}$ of $\mathrm{Zn}$.

\section{Decolorization of RY2 by LT10 at different levels of $\mathbf{Z n}$}

While studying the ability of the strain LT10 for RY2 decolorization at varying levels of $\mathrm{Zn}$, it was found that this strain exhibited complete RY2 decolorization even at $800 \mathrm{mg} / \mathrm{L}$ of $\mathrm{Zn}$ (Figure 4).

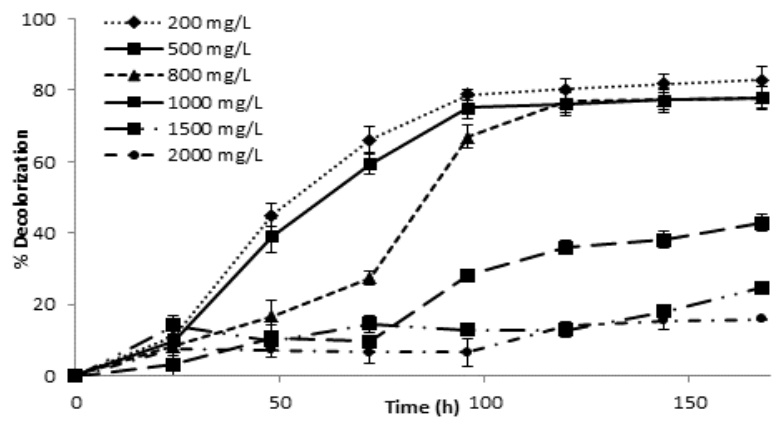

Fig-4: Effect of different levels of zinc (Zn) on removal of RY2 by Pseudomonas sp. LT10.

Table-2. Removal of dyes by Pseudomonas sp. LT10 in the presence of $200 \mathrm{mg} \mathrm{L}^{-1}$ of Zn

\begin{tabular}{|l|c|c|c|c|c|c|}
\hline & \multicolumn{7}{|c|}{ Color removal \% } \\
\hline & 24 Hours & $\mathbf{4 8 ~ H o u r s}$ & $\mathbf{7 2 ~ H o u r s}$ & $\mathbf{9 6}$ Hours & $\mathbf{1 2 0}$ Hours & $\mathbf{1 4 4}$ Hours \\
\hline Reactive Black-5 & $55.66 \pm 0.02$ & $67.20 \pm 0.07$ & $79.16 \pm 0.02$ & $75.49 \pm 0.02$ & $75.80 \pm 0.07$ & $87.24 \pm 0.02$ \\
\hline Reactive Orange-16 & Nil & Nil & $10.8 \pm 0.1$ & $87.79 \pm 0.02$ & $92.77 \pm 0.06$ & $93.41 \pm 0.05$ \\
\hline Reactive Red-120 & $0.12 \pm 0.15$ & $21.78 \pm 5.23$ & $29.79 \pm 0.02$ & $88.61 \pm 0.38$ & $93.73 \pm 0.07$ & $94.11 \pm 0.02$ \\
\hline Reactive Yellow-2 & $3.31 \pm 0.02$ & $11.58 \pm 0.02$ & $18.14 \pm 0.02$ & $22.44 \pm 0.54$ & $43.97 \pm 0.06$ & $70.80 \pm 0.1$ \\
\hline Congo Red direct & $67.08 \pm 0.12$ & $67.30 \pm 0.03$ & $69.21 \pm 0.18$ & $71.30 \pm 0.03$ & $72.38 \pm 0.03$ & $73.40 \pm 0.59$ \\
\hline Orange direct & $12.66 \pm 1.9$ & $14.14 \pm 0.37$ & $19.41 \pm 0.73$ & $22.78 \pm 0.63$ & $27.43 \pm 0.37$ & $32.91 \pm 1.9$ \\
\hline Blue Disperse & Nil & Nil & Nil & $55.59 \pm 0.01$ & $55.89 \pm 0.02$ & $56.13 \pm 0.11$ \\
\hline Violet Disperse & Nil & Nil & Nil & Nil & Nil & Nil \\
\hline
\end{tabular}


Abdul Mateen Baig et al.

The maximum value of RY2 decolorization by strain LT10 at 200 and $500 \mathrm{mg} / \mathrm{L}$ of Zn was obtained after $96 \mathrm{~h}$. Over this incubation period, 61.3, 25.7, 11.4 and $7.6 \%$ of the primarily added RY2 was removed at 800 , 1000, 1500 and $2000 \mathrm{mg} \mathrm{L}^{-1}$ of $\mathrm{Zn}$. However over 168 $\mathrm{h}$ incubation period, 42.3, 22.6 and $16.9 \%$ RY2 was removed at 1000,1500 and $2000 \mathrm{mg} \mathrm{L}^{-1}$ of $\mathrm{Zn}$. This finding indicates that the higher concentrations of $\mathrm{Zn}$ in the media inhibited the decolorization activity and this inhibited might due to the impact of $\mathrm{Zn}$ on the enzymatic system of the strain. These findinds were in accordance to the findings of Hafeez et al. (2018) who reported that Pseudomonas aeruginosa strain HF5 showed efficient color removal of RR120 up to 100 $\mathrm{mg} / \mathrm{L}$ of lead $(\mathrm{Pb})$ over which the decolorization activity was significantly inhibited.

\section{Color removal of structurally different dyes by strain LT10}

The strain LT10 revealed very good potential for color removal of structurally dissimilar dyes in the existence of $\mathrm{Zn}$ as shown in Table 2. However, it was observed that the ability of LT10 to decolorize structurally different dyes was variable. This variability in decolorization capability might be due to differences in structure of the dye molecules. Such difference in color removal of structurally dissimilar dyes has already been reported in various studies (Hussain et al., 2013; Hafeez et al., 2018; Maqbool et al., 2018).

\section{Conclusion}

Based on results, it can be concluded that Pseudomonas sp. strain LT10 has considerable ability for color removal of RY2. However, the strain LT10 exhibited efficient decolorization color removal of $\mathrm{RY} 2$ in the presence of yeast extract at $\mathrm{pH}$ 7.5-8.5. Moreover, Pseudomonas sp. strain LT10 efficiently decolorized RY2 dye even at higher levels of $\mathrm{Zn}$. Therefore, the strain LT10 can be considered as a potential candidate for its possible application for treatment of dye contaminated stuff.

\section{Acknowledgment}

Authors acknowledge the financial support of Higher Education Commission (HEC) of Pakistan in this research project through its NRPU grant No. 8206/Punjab/NRPU/R\&D/HEC/2017
Disclaimer: None.

Conflict of Interest: None.

Source of Funding: This research work was funded by Higher Education Commission of Pakistan under NRPU Project No. 8206/Punjab/NRPU/R\&D/HEC/2017.

\section{References}

Afreen S, Anwer R, Singh RK and Fatma T, 2016. Extracellular laccase production and its optimization from Arthrospira maxima catalyzed decolorization of synthetic dyes. Saudi J. Biol. Sci. 25(7): 1446-1453.

Anwar F, Hussain S, Ramzan S, Hafeez F, Arshad M, Imran M, Yasmeen $\mathrm{T}$ and $\mathrm{N}$ Abbas, 2014. Characterization of reactive red-120 decolorizing bacterial strain Acinetobacter junii FA10 capable of simultaneous removal of azo dyes and hexavalent chromium. Water Air Soil Pollut. 225: 1-16.

Ayed L, Bekir K, Achour S, Cheref A and Bakhrouf A, 2017. Exploring bioaugmentation strategies for azo dye CI Reactive Violet 5 decolourization using bacterial mixture: dye response surface methodology. Water Environ. J. 31(1): 80-89.

Carliell CM, Barclay SJ, Naidoo N, Buckley CA, Mulholland DA and Senior, 1995. Microbial decolourisation of a reactive azo dye under anaerobic conditions. Water SA. 21: 61-69.

Chacko JT and Subramaniam K, 2011. Enzymatic degradation of azo dyes, a review. Int. J. Environ. Sci. 1: 1250-1260.

Dawkar VV, Jadhav UU, Jadhav SU and Govindwar SP, 2008. Biodegradation of disperse textile dye brown 3REL by newly isolated Bacillus sp VUS. J. Appl. Microbiol. 105: 14-24.

Elisangela F, Andrea Z, Guimaro D, Menezes RDe, Lucia D and Artur C, 2009. Biodegradation of textile azo dyes by a facultative Staphylococcus arlettae strain $\mathrm{VN}-11$ using a sequential microaerophilic / aerobic process. Int. Biodeterior. Biodegrad. 63(3): 280-288.

Ghodake GS, Kalme SD, Jadhav JP and Govindwar SP, 2009. Purification and partial characterization of lignin peroxidase from Acinetobacter calcoaceticus NCIM 2890 and its application in decolorization of textile dyes. Appl. Biochem. Biotechnol. 152: 6-14.

Hafeez F, Farheen H, Mahmood F, Shahzad T, Shahid M, Iqbal M, Sumaira R and Hussain S, 2018. Isolation and characterization of a lead $(\mathrm{Pb})$ 
tolerant Pseudomonas aeruginosa strain HF5 for decolorization of reactive red-120 and other azo dyes. Ann. Microbiol. 68(12): 943-952.

Hussain S, Maqbool Z, Ali S, Yasmeen T, Imran M, Mahmood F and Abbas F, 2013. Biodecolorization of reactive black- 5 by a metal and salt tolerant bacterial strain Pseudomonas sp. RA20 isolated from Paharang drain effluents in Pakistan. Ecotoxicol. Environ. Saf. 98: 331-338.

Hussain S, Quinn L, Li J, Casey E and Murphy CD, 2017. Simultaneous removal of malachite green and hexavalent chromium by Cunninghamella elegans bio film in a semi-continuous system. Int. Biodeterior. Biodegrad. 125:142-149.

Imran M, Arshad M, Asghar HN, Asghar M and Crowley DE, 2014. Potential of Shewanella sp. strain IFN4 to decolorize azo dyes under optimal conditions. Int. J. Agric. Biol. 16(3): 578-584.

Imran M, Arshad M, Negm F, Khalid A, Shaharoona B, Hussain S, Nadeem SM and Crowley DE, 2016. Yeast extract promotes decolorization of azo dyes by stimulating azoreductase activity in Shewanella sp. strain IFN4. Ecotoxicol. Environ. Saf. 124: 4249.

Imran M, Crowley DE, Khalid A, Hussain S, Mumtaz MW and Arshad M, 2015. Microbial biotechnology for decolorization of textile wastewater. Rev. Environ. Sci. Biotechnol. 14(1): 73-92.

Jadhav JP, Phugare SS, Dhanve RS and Jadhav SB, 2010. Rapid biodegradation and decolorization of Direct orange 39 (Orange TGLL) by an isolated bacterium Pseudomonas aeruginosa strain $\mathrm{BCH}$. Biodegrad. 21(3): 453-463.

Khadhraoui M, Trabelsi H, Ksibi M, Bouguerra S and Elleuch B, 2009. Discoloration and detoxicification of a Congo red dye solution by means of ozone treatment for a possible water reuse. J. Hazard. Mater. 161: 974-981.

Khalid A, Kausar F, Arshad M, Mahmood T and Ahmed I, 2012. Accelerated decolorization of reactive azo dyes under saline conditions by bacteria isolated from Arabian seawater sediment. Appl. Microbiol. Biotechnol. 96: 1599-1606.

Kusic H, Juretic D, Koprivanac C, Marin V and Bozic $\mathrm{Al}, 2011$. Photooxidation processes for an azo dye in aqueous media: modeling of degradation kinetic and ecological parameters evaluation. J. Hazard. Mater. 185: 1558-1568.

Mahmood S, Khalid A, Mahmood T, Arshad M and Ahmad R, 2012. Potential of newly isolated bacterial strains for simultaneous removal of hexavalent chromium and reactive black- 5 azo dye from tannery effluent. J. Chem. Technol. Biotechnol. 88(8): 1506-1513.

Maqbool Z, Hussain S, Ahmad T and Nadeem H, 2016. Use of RSM modeling for optimizing decolorization of simulated textile wastewater by Pseudomonas aeruginosa strain ZM130 capable of simultaneous removal of reactive dyes and hexavalent chromium. Environ. Sci. Pollut. Res. 23(11): 11224-11239.

Maqbool Z, Hussain S, Mahmood F, Shahid M, Shahzad T, Ahmed T, Sahar A, Imran M, Ahmad $\mathrm{Z}$ and Hafeez F, 2018. Metal-Tolerant Pseudomonas aeruginosa Strain ZM130 has the potential for concurrent dye decolorization and plant growth promotion. Int. J. Agric. Biol. 20(12): 2621-2631.

Meerbergen K, Willems KA, Dewil R, Impe JV, Appels L and Lievens B, 2018. Isolation and screening of bacterial isolates from wastewater treatment plants to decolorize azo dyes. J. Biosci. Bioeng. 125(4): 448-456.

Mittal A, Kurup L and Gupta VK, 2005. Use of waste material bottom ash and de-oiled soya, as potential adsorbents for the removal of amaranth from aqueous solutions. J. Hazard. Mater. 117: 171-178.

Mondal P, Baksi S and Bose D, 2017. Study of environmental issues in textile industries and recent wastewater treatment technology. World Sci. News. 61(2): 98-109.

Najme R, Hussain S, Maqbool Z, Imran M, Mahmood F, Manzoor H, Yasmeen T and Shehzad T, 2015. Biodecolorization of Reactive Yellow-2 by Serratia sp. RN34 isolated from textile wastewater. Water Environ. Res. 87(12): 2065-2075.

Phugare SS, Kalyani DC, Patil AV and Jadhav JP, 2011. Textile dye degradation by bacterial consortium and subsequent toxicological analysis of dye and dye metabolites using cytotoxicity, genotoxicity and oxidative stress studies. J. Hazard. Mater. 186: 713-723.

Roy DC, Biswas SK, Saha AK, Sikdar B, Rahman M, Roy AK, Prodhan ZH and Tang SS, 2018. Biodegradation of Crystal Violet dye by bacteria isolated from textile industry effluents. Peer J. 6: 5001-5015.

Saratale RG, Saratale GD, Chang JS and Govindwar SP, 2009. Decolorization and biodegradation of textile dye Navy blue HER by Trichosporon beigelii NCIM- 3326. J. Hazard. Mater. 166: 1421-1428. 
Tripathi A and Srivastave SK, 2011. Ecofriendly treatment of azo dyes bio decolorization using bacterial Strain. Int. J. Biosci. Biochem. Bioinform. 1: 37-40.

Verma AK, Dash RR and Bhunia P, 2012. A review on chemical coagulation/flocculation technologies for removal of colour from textile wastewaters. J. Environ. Manage. 93(1):154-168.

Verma P and Madamwar D, 2003. Decolourization of synthetic dyes by a newly isolated strain of Serratia marcescens. World J. Microbiol. Biotechnol. 19(6): 615-618.

\section{Contribution of Authors}

Baig AM: Data collection and manuscript writing Sarwar T: Statistical analysis

Taj L: Data interpretation Bilal Y: Manuscript writing Mazhar E: Designed research methodology

Elahi HR: Literature search

Iqbal MM: Statistical analysis

Rasheed A: Manuscript final reading

Maqbool Z: Data interpretation

Hussain S: Conceived idea and manuscript final approval 